"Mircea cel Batran" Naval Academy Scientific Bulletin, Volume XIX - 2016 - Issue 2

\title{
ASSESSMENT OF THE WIND POTENTIAL FOR THE NORTH-WESTERN AREA OF THE BLACK SEA BY INTERPRETING DATA RECORDED BY METEOROLOGICAL SATELLITES AND METEOROLOGICAL COSTAL STATIONS AND THE EXPLOITATION OF THIS INFORMATION BY VESSELS ENGAGED ON COASTAL ROUTES
}

\author{
Dinu ATODIRESEI ${ }^{1}$ \\ Alexandru COTORCEA ${ }^{2}$ \\ Alexandru SERBAN ${ }^{3}$ \\ Emil DUMITRELE ${ }^{4}$
}

${ }^{1}$ Adv. Instructor, PhD, Department of Maritime and River Navigation and Transportation ,,Mircea cel Batran”
Naval Academy, Constanta, Romania, dinu.atodiresei@anmb.ro
${ }^{2}$ Instructor, Eng., PhD student, Department of Naval and Port Engineering and Management, ,,Mircea cel
Batran” Naval Academy, Constanta, Romania, alexandru.cotorcea@anmb.ro
${ }^{3}$ Student Department of Maritime and River Navigation and Transportation ,,Mircea cel Batran” Naval
Academy, Constanta, Romania, alexandru.serban@student.anmb.ro
${ }^{4}$ Eng., Maritime Officer Constanta, Romania,

\begin{abstract}
The subject of this paper is to assess the wind potential for the north-western area of the Black Sea based on satellite recorded data supplied by "ASCAT" (Advanced SCATterometer) and from meteorological costal stations for the purpose of utilizing this data onboard commercial ships in order to efficiently produce renewable energy. The evaluation of the benefits obtained by capitalizing wind power, thus producing renewable energy using contemporary technical solutions already existing within the maritime industry, has been achieved by comparing energy production costs between onboard diesel generators and wind turbines across various types of ships.
\end{abstract}

Key words: ASCAT, Advanced SCATterometer, renewable energy, meteorological data analysis, wind energy

\section{Introduction}

Due to its geographical position, the climate of the Black Sea is influenced in general by continental air masses, polar and tropical marine; their provenance having various directions. Maritime tropical air masses appear as a result of the southwest winds from the Mediterranean Sea, during the winter polar air masses from North and $\mathrm{N}-\mathrm{E}$, these are responsible for bringing within the basin, low temperatures and frequent storms [1]. Short-term weather patterns in the watershed are influenced by the North Atlantic Oscillation (NAO) and by the EI Nino Southern Oscillation (ENSO), these two being responsible for the necessary conditions of cyclone formation and transport of cold air masses over the warm waters of the sea [2]. Additionally, these two weather systems also reduce the force of the polar air masses which are originating in the winter from in the Northern areas. The areas which are subject to both systems, NAO and respectively ENSO, influence the rate of occurrence of storms over the Mediterranean, being directly involved in the variability of cyclones, thus the number is higher during the winter in the Black Sea area [3]. Past studies on wind speed indicates increased activity in the western part of the sea, with an average wind speed of $5 \mathrm{~m} / \mathrm{s}$ during summer time and about $8 \mathrm{~m} / \mathrm{s}$ during the winter [4].

However, it is generally accepted that wind variations in the western part of the Black Sea record large seasonal variations, while the eastern part is characterized by more stable conditions [5]. During the winter, storm conditions arise, especially in the west, under the influence of the Easterly and Northeasterly winds. During the storms, the wind can easily exceed $40 \mathrm{~m} / \mathrm{s}$ on the open sea and $25 \mathrm{~m} / \mathrm{s}$ closer to shore [6]. The wind is the most common form of air movement in the horizontal plane (while the atmosphere is made up of volumes of air with different characteristics in terms of heat and pressure, with permanent trend toward establishing a balance by the movements of air in the vertical or horizontal plan).

The wind is a physical phenomenon which manifests itself as a directed movement of air in the earth's atmosphere. The wind intensity and 
"Mircea cel Batran" Naval Academy Scientific Bulletin, Volume XIX - 2016 - Issue 2 The journal is indexed in: PROQUEST / DOAJ / Crossref / EBSCOhost / INDEX COPERNICUS / DRJI / OAJI I JOURNAL INDEX / I2OR / SCIENCE LIBRARY INDEX / Google Scholar / Academic Keys/ ROAD Open Access I Academic Resources / Scientific Indexing Services / SCIPIO I JIFACTOR

duration depend on the pressure difference exerted between the two endpoints.

Air movement in the form of wind is made from high to low atmospheric pressure. Movement is done generally in this direction, but may change due to the rotational motion (the Coriolis force), which imposes deviations to the right in the Northern Hemisphere and clockwise in the southern hemisphere.
2. Methods used to assess the energy potential

Regarding how to measure the wind potential in the northwestern area of the Black Sea, in this paper, we used two methods to asses this potential. The first is based on information collected from eight weather stations positioned along the northwestern coast of the Black Sea (Figure 1) and the second is based on a database of satellite data.

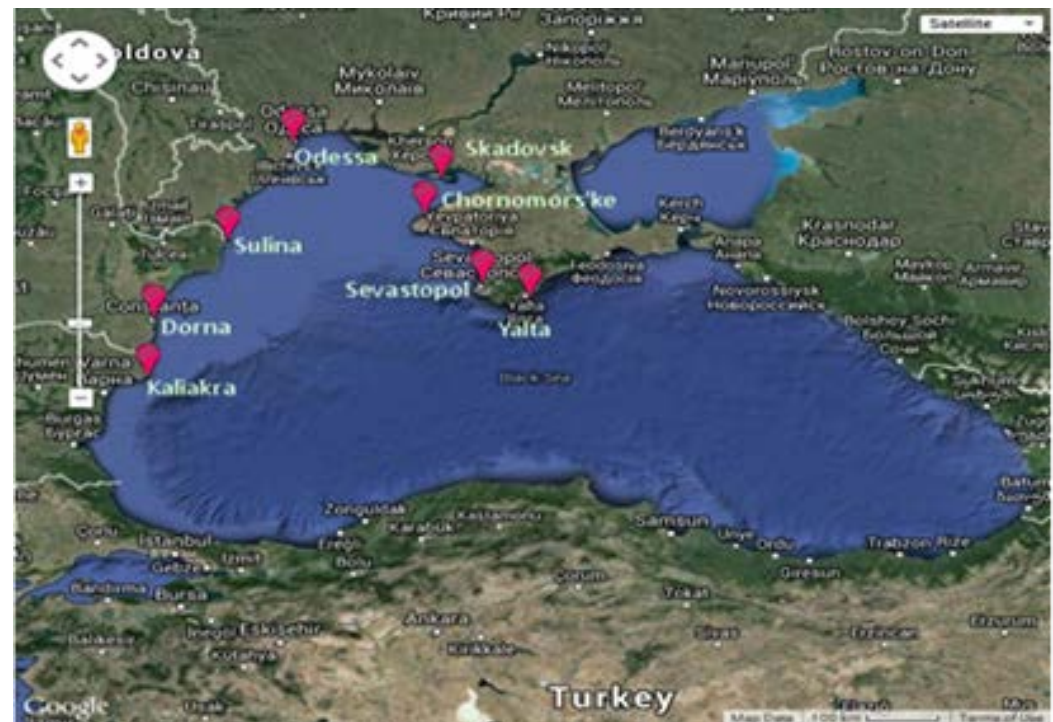

Fig 1. Layout of the weather stations along the northwestern coast of the Black Sea which were utilized to generate statistical data used in processing: 1. Kaliakra, Bulgaria; 2, 3 DornaMamaia, Sulina, Romania; 4, 5, 6,7,8 Odessa, Skadovsk, Chornomors'ke, Sevastopol, Yalta, Ukraine; (Adapted from https://maps.google.ro)

The statistics included were based on observations recorded daily between 7:00 a.m. to 7:00 p.m. (local time) for the periods specified for each station (Table 1), the data being provided according to synoptic situations presented on www.windfinder.com/weather [13].

The second method of evaluation of wind power potential is based on a database of satellite data. The information is generated by using Scatterometers, this is a microwave radar sensor used to scan the Earth's surface using the property of the electromagnetic waves of being reflected by the Earth.
Scatterometers used in the present study "ASCAT" (Advanced SCATterometer) is specially designed to scan large areas of water and determine wind speed and direction, at sea level. It operates in the C-band, using the frequency of $5.255 \mathrm{GHz}$.

ASCAT is installed onboard EUMETSAT MetOP. A satellite, the spatial resolution used is $0.25^{\circ}$ of latitude and longitude. Additionally, in determining the error, compared to the values of floating beacons, speed error is less than $1 \mathrm{~m} / \mathrm{s}$ and the wind direction error is less than $20^{\circ}$ [7].

Table 1 Measurement range of data for each station

\begin{tabular}{|l|c|c|}
\hline Name of the weather station & Period of record & Altitude [m] \\
\hline Kaliakra, Bulgaria & $03 / 2008-11 / 2013$ & 64 \\
\hline Dorna, Mamaia, Romania & $05 / 2012-01 / 2015$ & 4 \\
\hline Sulina, Romania & $03 / 2010-01 / 2015$ & 4 \\
\hline Odessa, Ukraine & $07 / 2007-01 / 2015$ & 42 \\
\hline Skadovsk, Ukraine & $06 / 2011-01 / 2015$ & 1 \\
\hline Chornomors'ke, Ukraine & $07 / 2007-01 / 2015$ & Sea level \\
\hline Sevastopol, Ukraine & $05 / 2012-01 / 2015$ & 165 \\
\hline Yalta, Ukraine & $03 / 2012-01 / 2015$ & 72 \\
\hline
\end{tabular}


"Mircea cel Batran" Naval Academy Scientific Bulletin, Volume XIX - 2016 - Issue 2

The journal is indexed in: PROQUEST / DOAJ / Crossref / EBSCOhost / INDEX COPERNICUS / DRJI / OAJI I JOURNAL INDEX / I2OR / SCIENCE LIBRARY INDEX / Google Scholar / Academic Keys/ ROAD Open Access I Academic Resources / Scientific Indexing Services / SCIPIO / JIFACTOR

ASCAT was first installed in 2006 and then in 2007 became fully functional and continues to operate today. Using ASCAT we can also determine polar ice, soil moisture and vegetation moisture.

Satellite information used in the assessment are provided in graphical form on the official website http://marine.copernicus.eu, concentrated in an interactive software. Each image contains data on speed and wind direction, date, time and height of observation. An example of such an image is shown below in Figure 2. Each image used in this study contains monthly information, image resolution consists of an amount of pixels, each covering an area of approximately $775 \mathrm{~km}^{2}$.

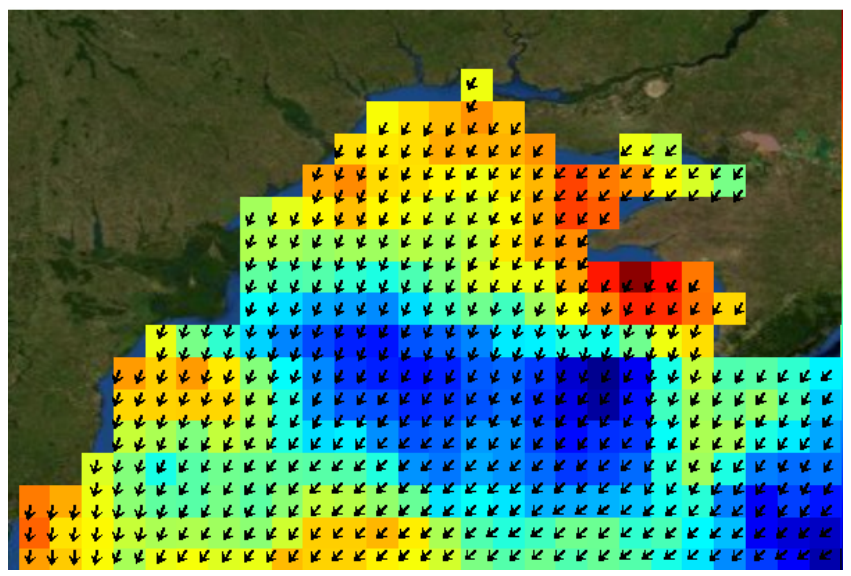

Figure 2: Sample image generated using ASCAT (source: http://marine.copernicus.eu)

Regarding the average wind speed, it was determined by arithmetic average of all pixels in the northwestern area of the Black Sea (Figure 2). All the information regarding the speed and wind direction used, are public on website MyOcean and on request they can be downloaded in compressed form. The information can then be opened with a variety of free software; these software options are also listed on the website mentioned above. The idea of downloading information and then placing them in specialized software is to convert the information provided in a graphical manner into a numerical chart.

The time interval used in the study is 01.201004.2012 , the height for the observations is $10 \mathrm{~m}$ above the water. The results presented in Chapter III have been generated by transforming the graphical data into numerical data.

\section{Results}

3.1 Statistics generated for wind related meteorological parameters (dominant direction, average speed and probability (\%) for a wind force> 4 Beaufort Scale) for the selected weather stations

Based on processing the information recorded by the selected weather stations, wind related meteorological parameters are as follows (Table 2).

Table 2 Statistics for wind meteorological parameters related to selected stations

\begin{tabular}{|c|c|c|c|c|c|c|c|c|c|c|c|c|c|}
\hline \multirow{2}{*}{ Month } & Jan & Feb & Mar & Apr & May & Jun & Jul & Aug & Sep & Oct & Nov & Dec & Annual \\
\cline { 2 - 13 } & 01 & 02 & 03 & 04 & 05 & 06 & 07 & 08 & 09 & 10 & 11 & 12 & $1-12$ \\
\hline \multicolumn{7}{|c|}{ a. Kaliakra, Bulgaria, UTC+2, observation height 64m } \\
\hline $\begin{array}{c}\text { Prevailing wind } \\
\text { direction ( })\end{array}$ & 315 & 315 & 225 & 45 & 45 & 225 & 45 & 45 & 45 & 45 & 90 & 315 & 45 \\
\hline $\begin{array}{c}\text { Wind probability of } \\
\text { speed>= 4 Beaufort (\%) }\end{array}$ & 55 & 49 & 58 & 46 & 39 & 29 & 45 & 56 & 48 & 48 & 41 & 62 & 48 \\
\hline $\begin{array}{c}\text { Average wind speed } \\
(\mathrm{Kn})\end{array}$ & 14 & 13 & 14 & 12 & 11 & 10 & 11 & 12 & 13 & 13 & 12 & 15 & 12 \\
\hline
\end{tabular}


"Mircea cel Batran" Naval Academy Scientific Bulletin, Volume XIX - 2016 - Issue 2 The journal is indexed in: PROQUEST / DOAJ / Crossref / EBSCOhost / INDEX COPERNICUS / DRJI / OAJI I JOURNAL INDEX I I2OR / SCIENCE LIBRARY INDEX / Google Scholar / Academic Keys/ ROAD Open Access I Academic Resources / Scientific Indexing Services / SCIPIO / JIFACTOR

\begin{tabular}{|c|c|c|c|c|c|c|c|c|c|c|c|c|c|}
\hline \multirow{2}{*}{ Month } & Jan & Feb & Mar & Apr & May & Jun & Jul & Aug & Sep & Oct & Nov & Dec & Annual \\
\hline & 01 & 02 & 03 & 04 & 05 & 06 & 07 & 08 & 09 & 10 & 11 & 12 & $1-12$ \\
\hline $\begin{array}{l}\text { Prevailing wind } \\
\text { direction }\left(^{\circ}\right)\end{array}$ & 315 & 90 & 90 & 67 & 45 & 157 & 90 & 67 & 90 & 90 & 0 & 315 & 90 \\
\hline $\begin{array}{c}\text { Wind probability of } \\
\text { speed }>=4 \text { Beaufort (\%) }\end{array}$ & 21 & 7 & 35 & 56 & 1 & 2 & 8 & 6 & 20 & 17 & 13 & 30 & 18 \\
\hline $\begin{array}{l}\text { Average wind speed } \\
(\mathrm{Kn})\end{array}$ & 6 & 4 & 9 & 12 & 3 & 4 & 5 & 5 & 7 & 6 & 5 & 8 & 6 \\
\hline \multicolumn{14}{|c|}{ c. Sulina, Romania, UTC+2, observation height $4 \mathrm{~m}$} \\
\hline $\begin{array}{l}\text { Prevailing wind } \\
\text { direction }\left(^{\circ}\right)\end{array}$ & 315 & 22 & 22 & 180 & 180 & 180 & 45 & 45 & 45 & 45 & 180 & 315 & 45 \\
\hline $\begin{array}{c}\text { Wind probability of } \\
\text { speed }>=4 \text { Beaufort (\%) }\end{array}$ & 54 & 63 & 62 & 57 & 47 & 44 & 37 & 41 & 48 & 54 & 53 & 62 & 51 \\
\hline $\begin{array}{l}\text { Average wind speed } \\
(\mathrm{Kn})\end{array}$ & 13 & 14 & 14 & 13 & 11 & 11 & 10 & 10 & 11 & 13 & 12 & 14 & 12 \\
\hline \multicolumn{14}{|c|}{ d. Odessa, Ukraine, UTC+3, observation height $42 \mathrm{~m}$} \\
\hline $\begin{array}{l}\text { Prevailing wind } \\
\text { direction }\left(^{\circ}\right)\end{array}$ & 67 & 45 & 180 & 180 & 180 & 180 & 180 & 22 & 22 & 22 & 202 & 45 & 180 \\
\hline $\begin{array}{c}\text { Wind probability of } \\
\text { speed }>=4 \text { Beaufort (\%) }\end{array}$ & 35 & 39 & 48 & 37 & 28 & 32 & 33 & 31 & 32 & 30 & 29 & 34 & 34 \\
\hline $\begin{array}{l}\text { Average wind speed } \\
(\mathrm{Kn})\end{array}$ & 10 & 10 & 11 & 11 & 9 & 10 & 10 & 10 & 10 & 10 & 9 & 10 & 10 \\
\hline \multicolumn{14}{|c|}{ e. Skadovsk, Ukraine, UTC+3, observation height $1 \mathrm{~m}$} \\
\hline $\begin{array}{l}\text { Prevailing wind } \\
\text { direction }\left(^{\circ}\right) \\
\end{array}$ & 45 & 45 & 270 & 225 & 225 & 157 & 270 & 270 & 45 & 202 & 45 & 292 & 45 \\
\hline $\begin{array}{l}\text { Wind probability of } \\
\text { speed }>=4 \text { Beaufort (\%) }\end{array}$ & 22 & 9 & 27 & 15 & 9 & 7 & 12 & 8 & 13 & 16 & 24 & 22 & 15 \\
\hline $\begin{array}{l}\text { Average wind speed } \\
(\mathrm{Kn})\end{array}$ & 7 & 7 & 8 & 8 & 6 & 5 & 7 & 6 & 7 & 7 & 8 & 9 & 7 \\
\hline \multicolumn{14}{|c|}{ f. } \\
\hline $\begin{array}{l}\text { Prevailing wind } \\
\text { direction }\left(^{\circ}\right) \\
\end{array}$ & 67 & 67 & 292 & 22 & 270 & 292 & 292 & 22 & 22 & 67 & 67 & 67 & 67 \\
\hline $\begin{array}{l}\text { Wind probability of } \\
\text { speed }>=4 \text { Beaufort (\%) }\end{array}$ & 39 & 47 & 43 & 40 & 23 & 25 & 23 & 26 & 35 & 36 & 33 & 42 & 34 \\
\hline $\begin{array}{l}\text { Average wind speed } \\
(\mathrm{Kn})\end{array}$ & 11 & 11 & 11 & 11 & 8 & 9 & 9 & 9 & 10 & 10 & 10 & 11 & 10 \\
\hline \multicolumn{14}{|c|}{ g. Sevastopol, Ukraine UTC+3, observation height 165 m } \\
\hline $\begin{array}{l}\text { Prevailing wind } \\
\text { direction }\left({ }^{\circ}\right)\end{array}$ & 247 & 202 & 315 & 247 & 247 & 315 & 337 & 337 & 315 & 45 & 135 & 112 & 247 \\
\hline $\begin{array}{c}\text { Wind probability of } \\
\text { speed }>=4 \text { Beaufort (\%) }\end{array}$ & 16 & 16 & 27 & 18 & 13 & 20 & 20 & 16 & 24 & 13 & 8 & 13 & 17 \\
\hline $\begin{array}{l}\text { Average wind speed } \\
(\mathrm{Kn})\end{array}$ & 6 & 6 & 7 & 7 & 6 & 7 & 7 & 7 & 7 & 6 & 4 & 5 & 6 \\
\hline \multicolumn{14}{|c|}{ h. Yalta, Ukraine, UTC+3, observation height $72 \mathrm{~m}$} \\
\hline $\begin{array}{l}\text { Prevailing wind } \\
\text { direction }\left(^{\circ}\right)\end{array}$ & 90 & 67 & 270 & 90 & 90 & 90 & 135 & 112 & 90 & 90 & 90 & 90 & 90 \\
\hline $\begin{array}{c}\text { Wind probability of } \\
\text { speed }>=4 \text { Beaufort (\%) }\end{array}$ & 4 & 7 & 8 & 9 & 2 & 8 & 2 & 2 & 14 & 9 & 3 & 4 & 6 \\
\hline $\begin{array}{l}\text { Average wind speed } \\
(\mathrm{Kn})\end{array}$ & 4 & 4 & 4 & 5 & 4 & 5 & 5 & 3 & 6 & 5 & 4 & 4 & 4 \\
\hline
\end{tabular}


"Mircea cel Batran" Naval Academy Scientific Bulletin, Volume XIX - 2016 - Issue 2 The journal is indexed in: PROQUEST / DOAJ / Crossref / EBSCOhost / INDEX COPERNICUS / DRJI / OAJI I JOURNAL INDEX I I2OR / SCIENCE LIBRARY INDEX / Google Scholar / Academic Keys/ ROAD Open Access I Academic Resources / Scientific Indexing Services / SCIPIO / JIFACTOR

The distribution of the average annual values of the wind speed for each district's weather station is shown in Figure 3.

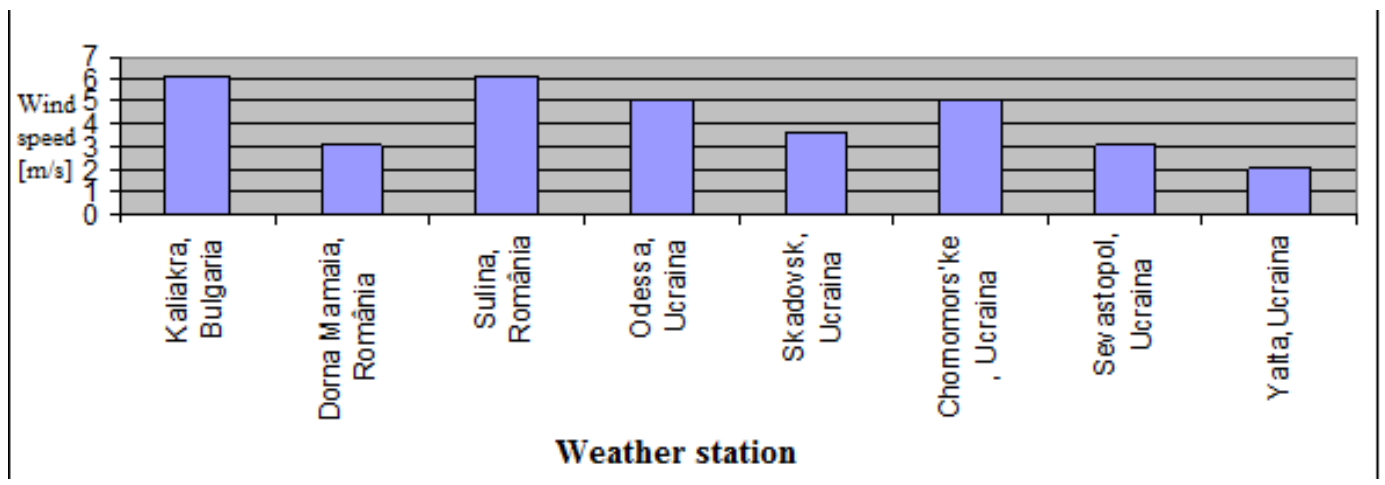

Figure 3 The distribution of the average annual values of the wind speed for selected stations

3.2 General meteorological statistics for parameters related to wind (Prevailing wind direction and medium speed) through the interpretation of satellite data.

For the year 2010 the average wind speed recorded the highest value in winter (January), being $8.11 \mathrm{~m} / \mathrm{s}$, the lowest recorded in May - 4 $\mathrm{m} / \mathrm{s}$. In Figure 4 the average wind speed values for the other months of 2010 (here can be seen average annual wind speed value of $6.11 \mathrm{~m} / \mathrm{s}$ ).

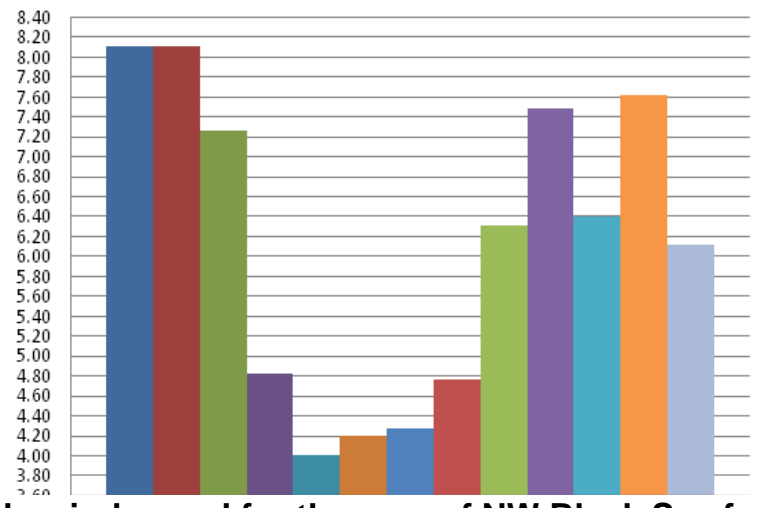

Figure 4 Average monthly wind speed for the area of NW Black Sea for 2010 based on satellite information

The results for year the 2011 are not very different from those of the previous year, so that the value of the highest monthly average wind speed was $8.75 \mathrm{~m} / \mathrm{s}$, recorded in February. In July it registered the lowest value of $3.8 \mathrm{~m} / \mathrm{s}$.
Average annual wind speed for 2011 was $5.9 \mathrm{~m} / \mathrm{s}$ (Figure 5). In the case of 2012, for the first 4 months under review, the average wind speed for January was $8.83 \mathrm{~m} / \mathrm{s}$, February $8.58 \mathrm{~m} / \mathrm{s}, 5.2$ in March and April of $7.28 \mathrm{~m} / \mathrm{s}$. 
"Mircea cel Batran" Naval Academy Scientific Bulletin, Volume XIX - 2016 - Issue 2

The journal is indexed in: PROQUEST / DOAJ / Crossref / EBSCOhost / INDEX COPERNICUS / DRJI / OAJI / JOURNAL INDEX / I2OR / SCIENCE LIBRARY INDEX / Google Scholar / Academic Keys/ ROAD Open Access I Academic Resources / Scientific Indexing Services / SCIPIO / JIFACTOR

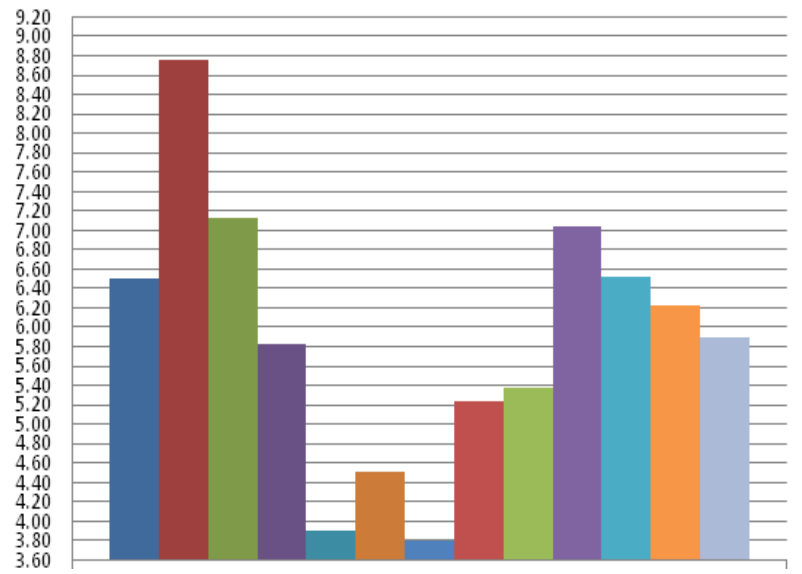

Figure 5 - Average monthly wind speed for the area of NW Black Sea for 2011 based on satellite information

By comparing the curves that describe the average wind speeds in the two years and three months analyzed (Figures 1 - 4) looming conclusion is that in winter the average wind speed recorded the highest value, then the passing of the winter season, there was a downtrend which lasted until July, when values have recorded an upward trend.

The average values of wind recorded during 01.2010-04.2012 were in the range $3.7-8.8 \mathrm{~m} / \mathrm{s}$, the highest values were recorded in December, January and February being established that the value of wind speed in the northwestern basin Black Sea is dependent on the time of year (Figure 6, 7).

Average speed for the two years examined in full is approximately equal, if in 2010 it was $6.1 \mathrm{~m} / \mathrm{s}$ in 2011 it was $5.9 \mathrm{~m} / \mathrm{s}$.

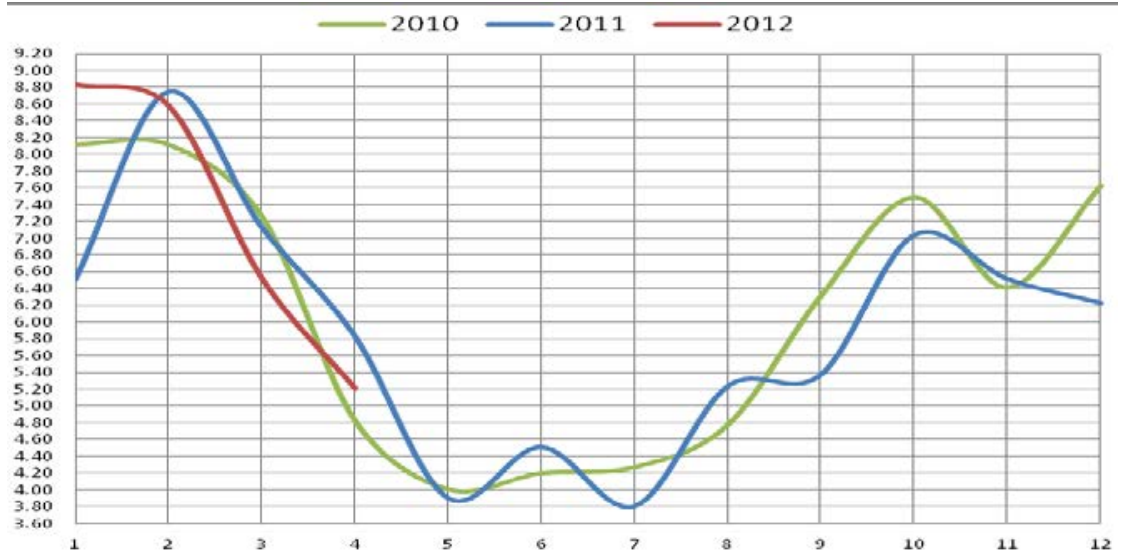

Figure 6 - Average monthly wind speed graph between January 2010 and April 2012 $37.10 \%$

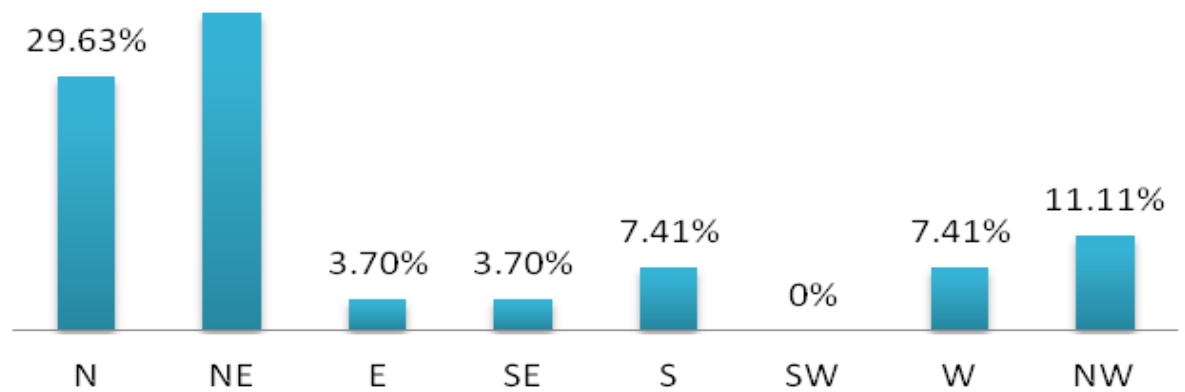

Figure 7 - Distribution of wind direction between January 2010 and April 2012 
"Mircea cel Batran" Naval Academy Scientific Bulletin, Volume XIX - 2016 - Issue 2

The journal is indexed in: PROQUEST / DOAJ / Crossref / EBSCOhost / INDEX COPERNICUS / DRJI / OAJI I JOURNAL INDEX I I2OR / SCIENCE LIBRARY INDEX / Google Scholar / Academic Keys/ ROAD Open Access I Academic Resources / Scientific Indexing Services / SCIPIO / JIFACTOR

4. Evaluating the information obtained in the determination of wind energy potential and assessing opportunities for use on board ships sailing on routes in the NW area of the Black Sea

4.1 Linking the two methods of evaluating wind power potential

Knowing that in the first method, height and observation interval ranged from one station to another and in the case of the second method the timeframe was between 2010 and April 2012 and the observation height was equal to $10 \mathrm{~m}$ above the sea level. In this case the relevant stations are Sulina, Skadovsk and Chornomors'ke. These stations are the ones which are located at a similar height and timeframe with the second method.

Therefore, if coastal stations average wind speed was within the range from 3.6 to $6.2 \mathrm{~m} / \mathrm{s}$ with an average of $4.9 \mathrm{~m} / \mathrm{s}$, a value very close to $6 \mathrm{~m} / \mathrm{s}$, the average velocity wind registered between
2010-2011 via satellite. Interestingly, the prevailing wind direction completely coincides in both cases as northeast.

4.2 Analysis of possible use of wind potential on board vessels sailing routes in the NW area of the Black Sea through the use of wind turbines

According to the European Wind Energy Agency report in 2014 [8]. average distance of installing wind turbines from land is $32,9 \mathrm{Km}$ and the average depth of installation thereof is $22,4 \mathrm{~m}$.

The possibilities for installation on board ships have been addressed through a variety of technical solutions widely described in the literature. Nominal energetic power on various turbine types are presented briefly in Table 3.

Table 3. Nominal power generated by different tyes of wind turbines (in kW)

\begin{tabular}{|c|c|c|c|c|c|c|}
\hline Model & Manufacturer & $\begin{array}{c}\text { Nominal power } \\
\text { (kW) }\end{array}$ & $\begin{array}{l}\text { Minimum wind } \\
\text { speed }(\mathrm{m} / \mathrm{s})\end{array}$ & $\begin{array}{l}\text { Rated wind } \\
\text { speed }(\mathrm{m} / \mathrm{s})\end{array}$ & $\begin{array}{c}\text { Maximum wind } \\
\text { speed }(\mathrm{m} / \mathrm{s})\end{array}$ & $\begin{array}{c}\text { Rotor } \\
\text { diameter }(m)\end{array}$ \\
\hline WES18 mk1 & WES & 80 & 2.7 & 12.5 & 25 & 18 \\
\hline GW 70/1500 & Goldwind & 1500 & 3 & 11.8 & 25 & 70 \\
\hline DeWind D8.2 & DeWind & 2000 & 4.5 & 15 & 25 & 80 \\
\hline MHI 2.4MW & Mitsubishi H.I. & 2400 & 3 & 12.5 & 25 & 92 \\
\hline WT2500-D103 & CSR Zhuzhou & 2500 & 3.5 & 11 & 23 & 103 \\
\hline V112 & MHI Vestas & 3300 & 3 & 12.5 & 25 & 112 \\
\hline Mervento 3.6 & Mervento & 3600 & 4 & 11.5 & 25 & 118 \\
\hline GE 4.1-113 & GE Energy & 4100 & 3.5 & 14 & 25 & 113 \\
\hline XD115 & XEMC & 5000 & 4 & 12 & 25 & 115 \\
\hline MingYang SCD & MingYang & 6000 & 3 & 13.6 & 22 & 140 \\
\hline $6.2 \mathrm{M} 126$ & Senvion & 6150 & 3.5 & 14 & 30 & 126 \\
\hline V164 & MHI Vestas & 8000 & 4 & 11 & 25 & 164 \\
\hline \multicolumn{2}{|c|}{ Avarage } & - & 3.48 & 12.62 & 25 & - \\
\hline \multicolumn{7}{|c|}{$\begin{array}{l}\text { Rated speed = minimum speed the turbine needs to generate nominal power; } \\
\text { Maximum speed = maximum speed at which the turbine cand work; above the speed the turbine will } \\
\text { stop immediately;[9]. }\end{array}$} \\
\hline
\end{tabular}




\section{"Mircea cel Batran" Naval Academy Scientific Bulletin, Volume XIX - 2016 - Issue 2 The journal is indexed in: PROQUEST / DOAJ / Crossref / EBSCOhost / INDEX COPERNICUS / DRJI / OAJI I JOURNAL INDEX / I2OR / SCIENCE LIBRARY INDEX / Google Scholar / Academic Keys/ ROAD Open Access I Academic Resources / Scientific Indexing Services / SCIPIO / JIFACTOR}

The values resulting from the study conducted and described above highlights that the average annual wind speed in 2010-2011 was $6 \mathrm{~m} / \mathrm{s}$, for a wind turbine with a capacity of $1500 \mathrm{~kW}$ (ex. GW 70/1500) amount of energy produced this half of its production capacity (since the rated speed of wind in this case is $11.8 \mathrm{~m} / \mathrm{s}$ ) is somewhere in $750 \mathrm{kWh}$.

The avarge price for each Mwh of offshore production from wind was in 2010 U.E €90 with real prospects of declining over time, predicting that by 2020 it will get somewhere around $74 € /$ MWh. [8].

Also in 2010 the price of a gallon of diesel was about \$3. [10].

If ship's ALEXANDER I (described in Table. 4) daily consumption of diesel for the generators on board (if she stands in the harbor or at anchor) was 38.4 Mwh.

Table 4. Diesel power generators on different types of ships[11].

\begin{tabular}{|l|l|c|r|r|r|}
\hline Ship's name & Ship type & Length(m) & DWT (t) & \multicolumn{2}{|c|}{ D.G. capacity (kW) } \\
\hline ALSTERDIJK & $\begin{array}{l}\text { Container (1436 } \\
\text { TEU) }\end{array}$ & 168 & 21.150 & $4 \times 1200=$ & 4800 \\
\hline AANALENA & $\begin{array}{l}\text { Container }(862 \\
\text { TEU) }\end{array}$ & 134 & 11.206 & $\begin{array}{r}1 \times 1112+1 \times 924 \\
=\end{array}$ & 2036 \\
\hline AB DUBLIN & General cargo & 90 & 4.211 & $2 \times 154+2 \times 136=$ & 580 \\
\hline ALEXANDER I & General cargo & 149 & 13.892 & $3 \times 800=$ & 2400 \\
\hline AEGEAN ACE & $\begin{array}{l}\text { Tanker } \\
\text { chemical/crude oil }\end{array}$ & 74 & 1.615 & $2 \times 144=$ & 288 \\
\hline ALLEGRA & $\begin{array}{l}\text { Tanker } \\
\text { chemical/crude oil }\end{array}$ & 180 & 40.438 & $3 \times 975.2=$ & 2927 \\
\hline AL DEEBEL & LNG & 283 & 71.868 & $3 \times 3.450=$ & 10350 \\
\hline ALPHAGAS & LNG/LPG & 114 & 6.399 & $3 \times 428.8=$ & 1286 \\
\hline & & & & & \\
\hline
\end{tabular}

It is known that a D.G. with a power of $800 \mathrm{~kW}$ consumes on average somewhere around 57 gal/h, two such D.G.s consuming about 114 gal/h.[12].

Considering the figures above we reach the following cost for the amount of energy produced by the diesel generators on board: costs would be $\$ 342 /$ hour $=\$ 8.208 /$ day $=\$ 57$ 456/week.
If for a week's time the ship would be connected to a system of power, based on wind turbines, the cost paid by the vessel for energy would be $€ 24$ 192 (\$30240, according eur/usd2010) or € 3456 I day ( $\$ 4320)$, cost almost twice lower than for diesel generators.

\section{CONCLUSIONS}

Taking into account the current concepts, propulsion systems based on wind power can not replace the main propulsion system of a ship but can at most to supplement it.

Another aspect is that usually ship owners are not the ones who pay the fuel consumption of ships but charterers, outlining the idea that interest is not necessarily from a ship owners' point of view to invest in energy-saving systems. Wind energy presents a great interest due to the relatively small cost paid for $1 \mathrm{MWh}$ energy compared with that paid for the same amount of power generated through diesel generators on board. The calculated price is so, much lower, which makes the idea of implementing a system of power based on wind turbine onboard ships to be taken very seriously into account.

The northwest area of the Black Sea basin is relatively calm in terms of winds. The amount of energy generated by wind power, as shown in the following evaluation, is relatively low. Wind speeds falling within $3,7-8,8 \mathrm{~m} / \mathrm{s}$. The optimum period for harnessing wind potential (with medium wind speeds over $6.5 \mathrm{~m} / \mathrm{s}$ ) on board ships is the cold season (October-March) according to the data processed.

\section{Acknowledgments}

This study has been conducted using E.U. Copernicus Marine Service Information. 
"Mircea cel Batran" Naval Academy Scientific Bulletin, Volume XIX - 2016 - Issue 2 The journal is indexed in: PROQUEST / DOAJ / Crossref / EBSCOhost / INDEX COPERNICUS / DRJI / OAJI I JOURNAL INDEX I I2OR / SCIENCE LIBRARY INDEX / Google Scholar / Academic Keys/ ROAD Open Access I Academic Resources / Scientific Indexing Services / SCIPIO I JIFACTOR

\section{BIBLIOGRAPHY}

[1] Valchev N., TrifonovaE., Andreeva N., Eftimova P., 2010 -Long-term variability of extreme storm occurrence and intensity in the western Black Sea.Storm Surges Congress 2010, Risk and Management of Current and Future Storm Surge, 13-17 September 2010, Hamburg, Germany.

[2] Efimov V.V.,Shokurov M.V., Yarovaya D.A., 2007 -Numerical simulation of a quasi-tropical cyclone over the Black Sea.Izv. Atmos. Oceanic Phys. 43: 723-743.

[3] Maslova V., Voskresenskaya E., Bardin M., 2010 - Variability of the cyclone activity in the Mediterranean-Black sea region. J. Environ. Prot. Ecol. 11: 1366-1372.

[4] Maslova Enriquez C.E., Shapiro GI., Zatsepin A.G., 2002 - Mesoscale circulation in the Black Sea during November 2000 from remote and in- situ data. Challeger Centenary Conference: Marine Science 2002, 9-13 September 2002, Plymouth, UK.

[5] Staneva J.V., Stanev E., 1998 -Oceanic response to atmospheric forcing derived from different climatic data sets. Intercomparison study for the Black Sea. Oceanol. Acta21: 393-417.

[6] Valchev N., Davidan I., Belberov Z., Palazov A., Valcheva N., 2008 -Estimation of wind wave climate of the Western Black Sea during the last 50 years. Proceedings of the Ninth International Conference on Marine Sciences and Technologies "Black Sea 2008", 23-25 October 2008, Varna, Bulgaria: 232-239.

[7] Tilly Driesenaar, AbderrahimBentamy, 2013 -Quality information document For the global ocean wind products wind_glo_wind_14_clim_observations_012_003

[8] http://www.ewea.org/ - The European Wind Energy Association

[9] http://www.4coffshore.com/windfarms/turbines.aspx

[10] http://www.eia.gov/ - Independent Statistics\&Analysis U.S Energy Information Administration

[11] http://www.scheepvaartwest.be/CMS/

[12] http://www.dieselserviceandsupply.com/diesel fuel consumption.aspx

[13] http://www.windfinder.com/weather. 